Ann. Biol. anim. Bioch. Biophys., 1979, 19 (4 B), 1339-1349.

\title{
Maturation of ovarian steroid biosynthetic pathways in puberty and their hormonal control
}

\author{
par K. MATSUMOTO, S. FUKUDA, N. TERAKAWA *, T. AONO *, K. KURACHI * \\ Instifute for Cancer Research, \\ * Department of Obstetrics and Gynecology, \\ Osaka University Medical School, Kifa-ku, Osaka 530, Japan.
}

Summary. In rats, mice and rhesus monkeys of different ages, radioactive $\left({ }^{14} \mathrm{C}\right.$ or $\left.{ }^{3} \mathrm{H}\right)$ progesterone, ${ }^{3} \mathrm{H}$-5 $\alpha$-pregnane-3,20-dione and/or ${ }^{34} \mathrm{C}$-testosterone were incubated with ovarian homogenate or directly injected into the ovary. After treatments, radioactive products in the incubation mixture and in the ovary or ovarian vein blood were extracted isolated, measured and identified.

All ovaries from rats, mice and monkeys of different ages converted significant amounis of progesterone to 17-hydroxyprogesterone, androstenedione and/or testosterone. Ovaries from immature rats and immature mice synthesized a significant quantity of $5 \alpha$-reduced $\mathrm{C}_{21}$-17-OH- and $\mathrm{C}_{19}$-steroids such as $3 \alpha, 17 \alpha$-dihydroxy-5 $\alpha$-pregnan-20-one, androsterone and $5 \alpha$-androstane-3 $\alpha, 17 \beta$-diol, whereas ovaries from suckling and adult rats and mice, and those from monkeys in all ages formed very little or no $5 \alpha$-reduced $\mathrm{C}_{21}-17-\mathrm{OH}$ and $\mathrm{C}_{19}$-steroids. These $5 \alpha$-androgens produced by immature rodent ovaries were shown to be synthesized mainly by a pathway through $5 \alpha$-reduced $C_{21}$-stéroids, which was regulated by LH but not by FSH or sex steroids.

\section{Introduction.}

Previous studies of androgen biosynthesis have demonstrated that rat and mouse testes of suckling and adult animals are capable of a high rate of progesterone conversion to testosterone. On the other hand, testes of immature rats and immature mice yield $5 \alpha$-reduced $C_{19}$-steroids ( $5 \alpha$-androgens) such as androsterone and $5 \alpha$-androstane-3 $\alpha, 17 \beta$-diol as major products (Inano et al., 1967 ; Coffey et al., 1971 ; Ficher and Steinberger, 1971 ; Tsujimura and Matsumoto, 1974 ; Yamada ef al., 1976). We also found by in vitro and in vivo studies that progesterone was converted to these $5 \alpha$-androgens primarily by a pathway through $5 \alpha$-reduced $C_{21}$-steroids $\left(C_{21}\right.$-5 $\alpha$-steroids) in these immature testes (Yamada and Matsumoto, 1974 ; Tsujimura et al., 1975 ; Yamada ef al., 1976).

Previous studies have demonstrated that immature rat ovary contains high $5 \alpha$-reductase activity (Mason, 1970) and that immature rat ovary forms a large quantity

Correspondence sends to : Matsumoto K. M. D., Institute for Cancer Research, Osaka University Medical School, Kita-ku, Osaka 530, Japan. 
of $5 \alpha$-androgens such as $5 \alpha$-androstane- $3 \alpha, 17 \beta$-diol, while adult rat ovary is unable to produce a significant quantity of $5 \alpha$-androgens (Springer and Eckstein, 1971 ; Eckstein and Ravid, 1974). These $5 \alpha$-androgens which can not be converted to cstrogen, have been shown to exert a negative feedback on gonadotrophin release and to induce precocious ovulation in rats (Eckstein and Ravid, 1974 ; Eckstein, 1975), Furthermore, ovariectomy of immature rats resulted in a marked increase in gonadotrophin level though plasma cestradiol-17 $\beta$ levels in the immature female rats were always the lowest (almost undetectable) (Meijs-Roelofs ef al., 1973). Since these findings indicate that the formation of $5 \alpha$-androgens in immature rat ovary seems to have a biological significance, the age-dependent patterns of $5 \alpha$-androgen formation which have been shown to be present in rat and mouse testes, should be clarified systematically in rat and mouse ovaries. In addition, a pathway leading to formation of these $5 \alpha$-androgens and hormonal regulation of $5 \alpha$-reductase activity in rodent ovary are also reported in this paper. Some findings on rat ovaries presented in this paper have already been reported in our previous papers (Karakawa ef al., 1976 ; Terakawa ef al., 1978).

In immature humans and immature monkeys, limited or no rise in gonadotrophin levels following castration has been reported (Odell and Swerdloff, 1976) and the formation of no or very small amounts of testicular $5 \alpha$-androgens has been found (Mizutani ef al., 1977). We are also reporting on the age-dependent pattern of $5 \alpha-$ androgen formation in rhesus monkey ovaries.

\section{Materials and methods.}

Animals. - Female rats of the Sprague-Dawley strain, female mice of the $d . d$. strain and female rhesus monkeys of different ages (suckling, immature, pubertal and adult animals) were used. In some experiments, female rats were hypophysectomized at 21 days of age, and treatment was started 3 days later. Rats were injected daily with $1-90 \mu \mathrm{g}$ of NIH-LH-S19, 10 or $50 \mu \mathrm{g}$ of NIAMD-Rat-FSH-B-1, $1 \mathrm{mg}$ of $5 \alpha$-androstane- $3 \alpha, 17 \beta$-diol, $1 \mathrm{mg}$ of testosterone or $20 \mu \mathrm{g}$ of $œ$ stradiol- $17 \beta$ for 3 days and were killed at 27 days of age.

Incubation procedure. - Homogenates of ovaries $(1-90 \mathrm{mg})$ of different ages were incubated with radioactive substrates $(1-6.6 \mathrm{nmol} / \mathrm{ml})$ and NADPH at $37{ }^{\circ} \mathrm{C}$ in $1 \mathrm{ml}$ medium as previously described (Karakawa ef al., 1976 ; Terakawa ef al., 1978).

Injection of radioactive steroids. - Radioactive progesterone and/or ${ }^{3} \mathrm{H}-5 \alpha$-pregnane-3,20-dione, each suspended in $5 \mu \mathrm{l}$ of saline solution were injected directly into rat ovary. The ovary and ovarian vein blood were obtained after the injection, and radioactive products were extracted.

Analysis and identification of steroids. - To the incubation mixtures and the extracts, 2-50 $\mu \mathrm{g}$ quantities of progesterone, $16 \alpha$-hydroxypregn-4-ene-3,20-dione, $20 \alpha$-hydroxypregn-4-en-3-one, $5 \alpha$-pregnane-3,20-dione, $3_{\beta}^{\alpha}$-hydroxy-5 $\alpha$-pregnan-20-one (5 $\alpha$-pregnanolones), 17 $\alpha$-hydroxypregn-4-ene-3,20-dione (17-hydroxyprogesterone), $17 \alpha$ hydroxy-5 $\alpha$-pregnane-3,20-dione, $3 \alpha, 17 \alpha$-dihydroxy-5 $\alpha$-pregnan-20-one, $3 \beta, 17 \alpha$ dihydroxy-5 $\alpha$-pregnan-20-one, androstenedione, testosterone, $5 \alpha$-androstane-3,17- 


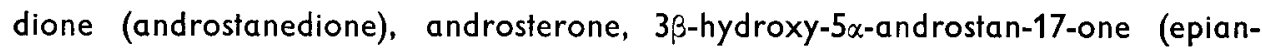
drosterone), $17 \beta$-hydroxy-5 $\alpha$-androstan-3-one (dihydrolestosterone), $5 \alpha$-androstane-

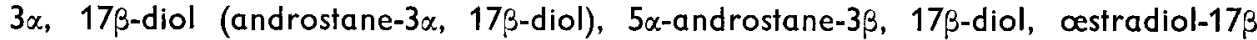
and/or ostrone were added as non radioactive carriers. The analysis of these steroids by paper (Zaffaroni and Burton, 1951) and column (Seki and Matsumoto, 1967) chromatography with acetylation of steroids, identification or tentative identification of metabolites by recrystallization to constant specific activity and the calculation of metabolite found in each steroid fraction were the same as previously described (Yamada et al., 1973 ; Karakawa ef al., 1976). $5 \alpha$-Reductase activity was estimated as previously described (Terakawa et al., 1978).

\section{Results.}

1. Metabolism of ${ }^{3} \mathrm{H}$-progesterone in rat ovaries of different ages.

The percentage formation of ${ }^{3} \mathrm{H}-4-$-ene-3-ketosteroids and ${ }^{3} \mathrm{H}-5 \alpha$-steroids from ${ }^{3} \mathrm{H}$-progesterone $(1 \mathrm{nmol})$ by $50 \mathrm{mg}$ of rat ovarian homogenate is shown in figure 1 . At 7 (suckling) and 70 (adult) days of age, the major $C_{19}$-steroids formed from progesterone were androstenedione and testosterone. At 20 and 30 days of age (immature), however, no accumulation of these $C_{19}$-4-ene-3-ketosteroids was found, at which

Progesterone and its derivatives

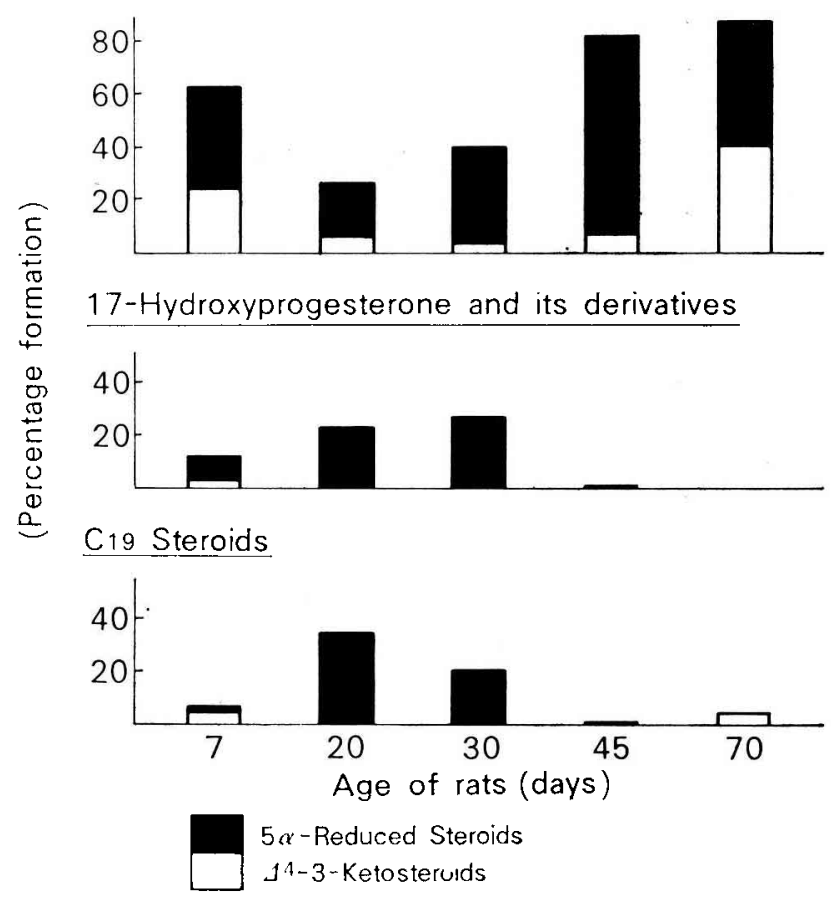

FIG. 1. - Percentage formation of ${ }^{3} \mathrm{H}$-steroids from ${ }^{3} \mathrm{H}$-progesferone by rat ovarian homogenates. Fifty $\mathrm{mg}$ tissue was incubated with ${ }^{3} \mathrm{H}$-progesterone $\left(1 \mathrm{nmol}: 1 \mu \mathrm{Ci}\right.$ per tube) at $37^{\circ} \mathrm{C}$ for $30 \mathrm{~min}$ in $1 \mathrm{ml}$. 
time the conversion of progesterone to $\mathrm{C}_{19}-5 \alpha$-steroids, such as androsterone and $5 \alpha$-androstane- $3 \alpha, 17 \beta$-diol, reached 30 p. 100. In these immature ovaries, the major $\mathrm{C}_{21}$-steroids formed from progesterone were $3 \alpha$-hydroxy-5 $\alpha$-pregnan-20-one and $3 \alpha$, $17 \alpha$-dihydroxy-5 $\alpha$-pregnan-20-one.

Radioactivity of ${ }^{3} \mathrm{H}-4-e n e-3-k e f o s t e r o i d s$ and ${ }^{3} \mathrm{H}-5 \alpha$-steroids found in ovary and ovarian vein blood following injection of ${ }^{3} \mathrm{H}$-progesterone into rat ovary is shown in figure 2. In immature rats, major $17-\mathrm{OH}-\mathrm{C}_{21}$ and $\mathrm{C}_{19}$-metabolites of progesterone were $5 \alpha$-steroids such as $3 \alpha, 17 \alpha$-dihydroxy-5 $\alpha$-pregnan-20-one and androsterone. A significant but small quantity of $5 \alpha$-androstane- $3 \alpha, 17 \beta$-diol was also found in the ovarian vein blood as well as in the ovary of immature rat. In adult rats, however, only small amounts of these $5 \alpha$-steroids were found, and $20 \alpha$-hydroxypregn-4-en-3-one was the major metabolite. Oestradiol $-17 \beta$ could be isolated in very small amounts only in adult ovaries.
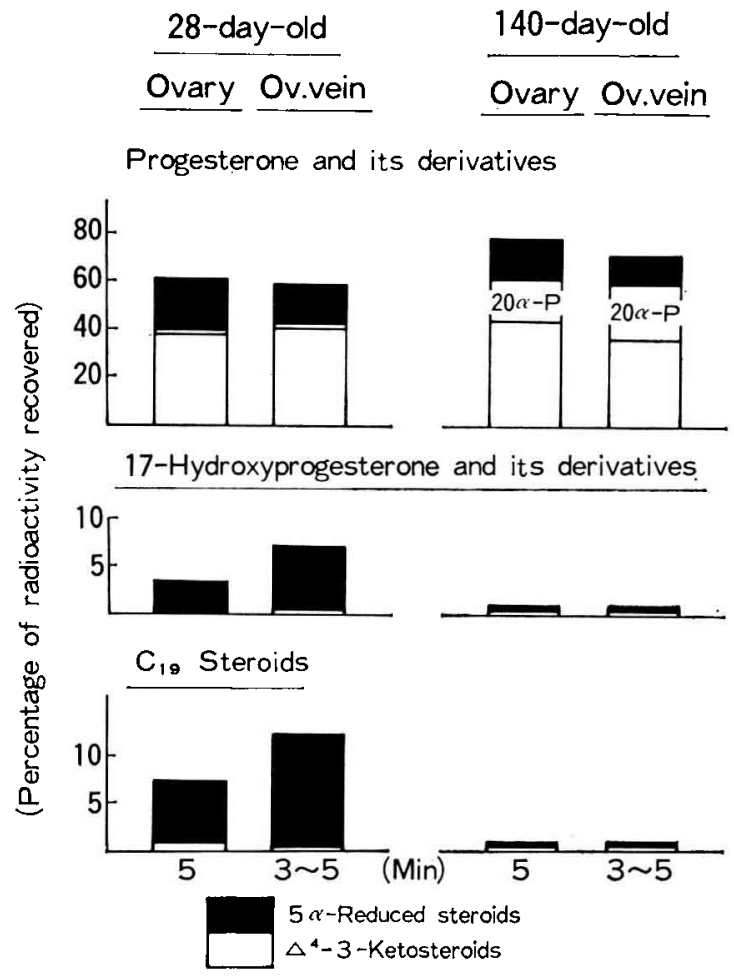

FIG. 2. - Radioactivity of ${ }^{3} \mathrm{H}$-steroids in ovary and ovarian vein blood following injection of ${ }^{3} \mathrm{H}$-progesterone $(0.6 \mathrm{nmol} / 30 \mu \mathrm{Ci}$ per $5 \mu \mathrm{l})$ into rat ovary.

2. Formation of $C_{19}-5 \alpha$-steroids from progesterone by a pathway through $C_{21}-5 \alpha$-steroids in immature rat ovary.

Since findings shown in figures 1 and 2 indicate that significant amounts of $5 \alpha-$ androgens are synthesized in immature rat ovaries but not in ovaries of suckling and 
adult rats, pathways leading to formation of these $5 \alpha$-androgens in the immature rat ovary have been investigated. Figure 3 shows the results when ${ }^{3} \mathrm{H}$-progesterone was incubated with homogenate from immature rat ovaries for varying periods. About 95 p. 100 of the precursor progesterone was converted to metabolites within the first $5 . \mathrm{min}$. A rapid increase in $3 \alpha$-hydroxy-5 $\alpha$-pregnan-20-one coccurred followed by declining amounts after $5 \mathrm{~min}$. 17-OH-C $\mathrm{C}_{21}-5 \alpha$-steroids such as $3 \alpha, 17 \alpha$-dihydroxy- $5 \alpha-$ pregnan-20-one accumulated between 15 and $45 \mathrm{~min}$ and then gradually decreased. $5 \alpha$-Androgens such as androsterone and $5 \alpha$-androstane- $3 \alpha, 17 \beta$-diol increased steadily and reached 70 p. 100 of the total radioactivity. 17-Hydroxyprogesterone, androstenedione and testosterone were almost undetectable throughout the entire incubation time.
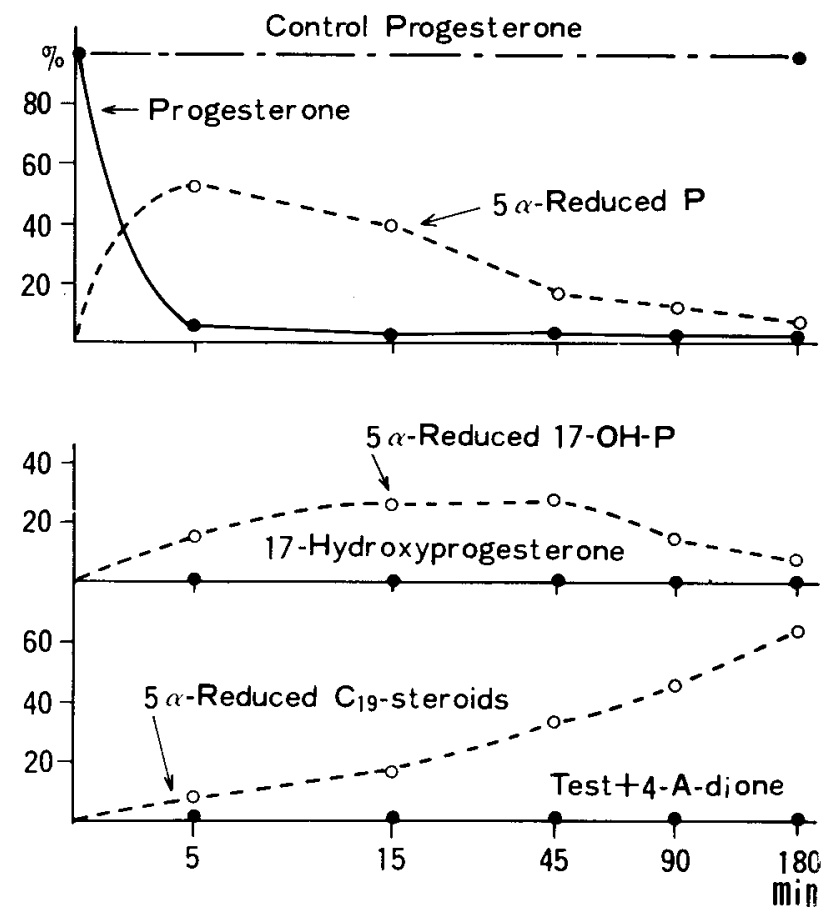

FIG. 3. - Percentage formation of ${ }^{3} \mathrm{H}$-steroids, at different time intervals following incubation of $50 \mathrm{mg}$ ovarian homogenate from 28 -day old rats with $1 \mathrm{nmol}$ of ${ }^{3} \mathrm{H}$-progesterone in $1 \mathrm{ml}$ at $37^{\circ} \mathrm{C}$. $\mathrm{P}$ : progesterone, 17-OH-P : 17-hydroxyprogesterone, Test : testosterone, 4-A-dione : androstenedione.

Experiments were attempted to determine ${ }^{3} \mathrm{H} /{ }^{14} \mathrm{C}$ ratios in $5 \alpha$-products following incubation of immature rat ovaries with ${ }^{3} \mathrm{H}-5 \alpha$-pregnane-3,20-dione plus ${ }^{14} \mathrm{C}$-progesterone or after injection of these two radioactive substrates into the im mature rat ovary (table 1). Significant augmentation of progesterone isotope was observed in $3 \alpha$, $17 \alpha$-dihydroxy-5 $\alpha$-pregnan-20-one compared with $3 \alpha$-hydroxy-5 $\alpha$-pregnan-20-one, indicating that $3 \alpha, 17 \alpha$-dihydroxy-5 $\alpha$-pregnan-20-one was formed from $3 \alpha$-hydroxy$5 \alpha$-pregnan-20-one and 17-hydroxyprogesterone. The ratios in $3 \alpha, 17 \alpha$-dihydroxy- 
$5 \alpha$-pregnan-20-one and $5 \alpha$-androgens showed a slight difference indicating that $5 \alpha$-androgens were mainly formed from $17-\mathrm{OH}-\mathrm{C}_{21}-5 \alpha$-steroids.

\section{TABLE 1}

Ratios of ${ }^{3} \mathrm{H}-5 \alpha$-pregnane-3,20-dione to ${ }^{14} \mathrm{C}$-progesterone as precursors of metabolites in immature rat ovary

\begin{tabular}{|c|c|c|c|}
\hline Condition & & & In vivo \\
\hline 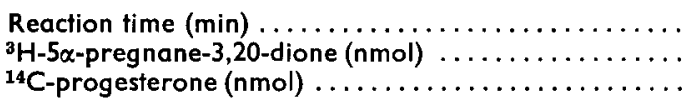 & $\begin{array}{l}30 \\
1.0 \\
6.6\end{array}$ & $\begin{array}{l}30 \\
6.6 \\
6.6\end{array}$ & $\begin{array}{l}2 \\
0.5 \\
6.6\end{array}$ \\
\hline 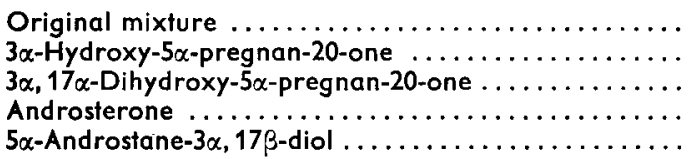 & $\begin{array}{l}1.00 \\
1.34 \\
0.82 \\
0.71 \\
0.44\end{array}$ & $\begin{array}{l}1.00 \\
1.17 \\
0.41 \\
0.33 \\
0.24\end{array}$ & $\begin{array}{l}1.00 \\
5.93 \\
0.95 \\
1.04 \\
0.80\end{array}$ \\
\hline
\end{tabular}

Ovarian homogenate $(50 \mathrm{mg})$ was incubated with ${ }^{3} \mathrm{H}$ - and ${ }^{14} \mathrm{C}$-substrates for $30 \mathrm{~min}$ at $37^{\circ} \mathrm{C}$ in $1 \mathrm{ml}$. In in vivo experiment, ${ }^{3} \mathrm{H}$ - and ${ }^{14} \mathrm{C}$-substrates suspended in $5 \mu \mathrm{l}$ of saline solution were directly injected into ovary and metabolites in the ovary were analyzed.

In ovaries of immature rats, the results obtained by in vitro and in vivo studies indicate two biosynthetic pathways leading to $5 \alpha$-androgens, one from progesterone via $C_{21}-5 \alpha$-steroids (major pathway), and the second via androstenedione and testosterone (fig. 4).

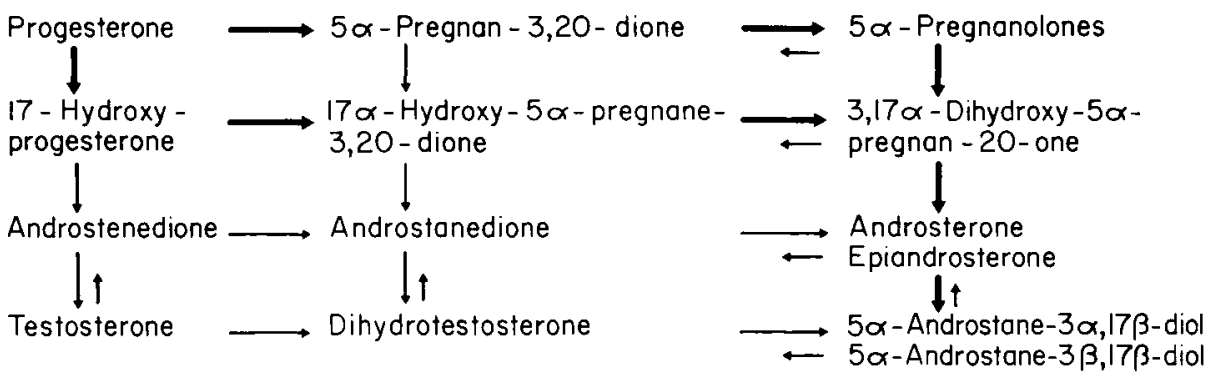

FIG. 4. - Metabolic pathways leading to formation of $5 \alpha$-androgens from progesterone in immolure rat ovary.

3. Hormonal regulation of $5 \alpha$-reductase activity in immature rat ovary.

The above observations in rats clearly show that efficient formation of $5 \alpha$-androgens by the $5 \alpha$-reduced pathway is present only in immature ovary. Since the formation of $5 \alpha$-androgens is stimulated by the presence of high $5 \alpha$-reductase activity in the 
immature rat ovary, hormonal regulation of the $5 \alpha$-reductase activity has been investigated.

Female rats were hypophysectomized at 21 days of age, and after a lapse of 3 days the hypophysectomized rats were injected daily with LH, FSH or sex steroids. At 27 days of age, $5 \alpha$-reductase activity in ovaries was measured. The $5 \alpha$-reductase activity ( $\mathrm{nmol} / \mathrm{g} / \mathrm{hr}$ ) decreased significantly 6 days following hypophysectomy. A distinct response to $\mathrm{LH}$ in $5 \alpha$-reductase activity of the hypophysectomized rat ovaries was found, with a dose-response in activity from $260 \pm 94$ (SD) in the hypophysectomized control to the maximum level of $1960 \pm 177$ (SD) $\mathrm{nmol} / \mathrm{g} / \mathrm{hr}$, using doses from 3 to $90 \mu \mathrm{g}$ per day. In contrast, FSH was not effective, for it had liftle effect on $5 \alpha$-reductase activity even when 10 or $50 \mu \mathrm{g}$ was given each day (fig. 5). No stimulation of $5 \alpha-$ re-

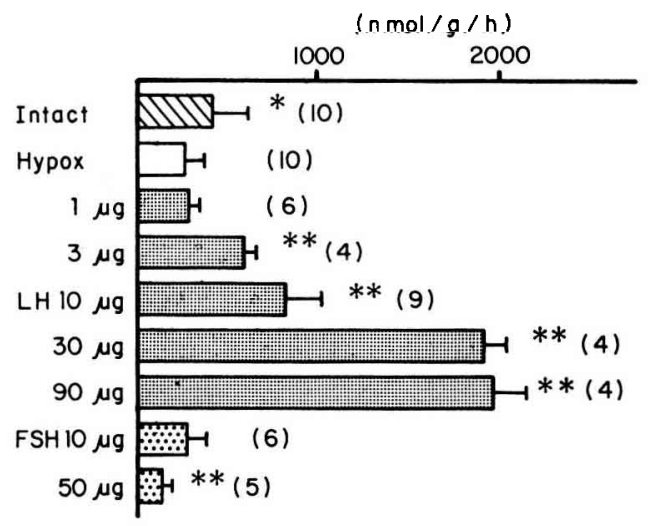

FIG. 5. - Effect of LH treatment and FSH treatment on $5 \alpha$-reductase activity $(\mathrm{nmol} / \mathrm{g} / \mathrm{hr}$ ) in ovaries of immafure hypophysectomized rats. Rats were hypophysectomized at 21 days of age, and treatment was started 3 days later. The rats were injected daily with 1-90 $\mu$ g of NIH-LH-S19 or 10-50 $\mu \mathrm{g}$ of NIAMD-Rat-FSH-B-1 for 3 days and were killed at 27 days of age. ( ) : No. of rats used. Differences from Hypox (hypophysectomized) control $(\mathrm{P}): *<0.05, * *<0.01$ (A t-fest was used).

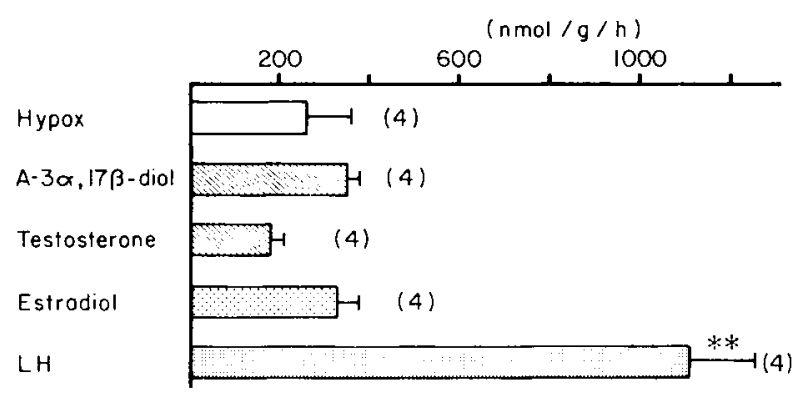

FIG. 6. - Effect of sex steroids and LH on $5 \alpha$-reductase activity in ovaries of immature hypophysectomized rats. Treatments are described in legend of figure 5 . The hypophysectomized rats were injected

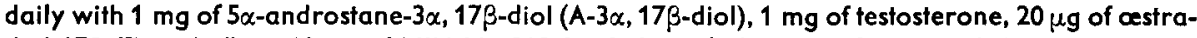
diol-17 $\beta$ (Estradiol) or $10 \mu \mathrm{g}$ of NIH-LH-S19 for 3 days. ( ) : No. of rats used. Difference from Hypox control $(\mathrm{P}): * *<0.01$ (A t-test was used). 
ductase activity was observed by injection of androgens and œstradiol-17 $\beta$ in large doses, showing that the effect of $\mathrm{LH}$ is not mediated by sex steroids. (fig. 6). The weight of ovaries increased from the hypophysectomized control by injection of FSH (approximately twice) but not by $\mathrm{LH}$ or sex steroids. These results show that $5 \alpha$-reductase activity in immature rat ovaries is regulated by $\mathrm{LH}$.

\section{Metabolism of ${ }^{3} \mathrm{H}$-progesterone in mouse and monkey ovaries of different ages.}

The age-dependent pattern of progesterone metabolism has also been examined in ovaries of rhesus monkeys and mice. All ovarian homogenates from monkeys and mice of different ages converted 10-80 p. 100 of progesterone to 17-hydroxyprogesterone, androstenedione, testosterone and/or 20 $\alpha$-hydroxypregn-4-en-3-one (figs. 7, 8). In monkeys, however, all ovaries of different ages (immature, pubertal and adult) formed no $5 \alpha$-metabolites of these 4-ene-3-ketosteroids (fig. 7). In mice, ovaries at 10 (suckling), 35 (puberfal) and 60 (adult) days of age were unable to form $\mathrm{C}_{21}-17-\mathrm{OH}$ $5 \alpha$-steroids and $\mathrm{C}_{19}-5 \alpha$-steroids whereas those at 21 and 28 days of age (immature) formed significant amounts of $3 \alpha, 17 \alpha$-dihydroxy-5 $\alpha$-pregnan-20-one, androsterone and $5 \alpha$-androstane- $3 \alpha, 17 \beta$-diol (fig. 8).

\section{Discussion.}

In rats, the formation of a large quantity of $5 \alpha$-androgens by the pathways through $C_{21}-5 \alpha$-steroids and $C_{19}$-4-ene-3-ketosteroids is present in immature ovaries but not in ovaries of suckling and adult animals (figs. 1-4, table 1). In contrast to immature rats, ovaries of immature as well as adult monkeys do not form a significant quantity of $5 \alpha$-androgens (fig. 7). Although ovaries of immature mice synthesize $5 \alpha$-androgens from progesterone, this age-dependent formation of $5 \alpha$-steroids is less active than that in rats (fig. 8). Ovariectomy of immature animals in which the uterus shows little stimulated effects by estrogens, results in a significant increase in gonadotrophin level in rats (Meijs-Roelofs ef al., 1973) but not in monkeys (Odell and Swerdloff, 1976). These observations suggest that the formation of $5 \alpha$-androgens in ovaries may be of biological significance in immature rodents. Although the $5 \alpha$-reductase in immature rat ovaries is shown to be maintained by LH (figs. 5 and 6), hormonal regulation of the age-dependent formation of $5 \alpha$-androgens in rodent ovaries hat not been satisfactorily clarified. Hormonal regulation of $5 \alpha$-reductase in ovaries of suckling and adult rats should be examined in future studies.

Efficient formation of $\mathrm{C}_{21}-17-\mathrm{OH}-5 \alpha$-steroids and $\mathrm{C}_{19}-5 \alpha$-steroids which is similar to that by immature rat ovaries (figs. 1-4) is present in immature rat testes (Inano et al., 1967 ; Coffey et al., 1971 ; Ficher and Steinberger, 1971 ; Yamada et al., 1976), and is present weakly in immature mouse testes (Tsujimura and Matsumoto, 1974), but is absent in immature monkey and human testes (Mizutani ef al., 1977). The previous findings and the present results seem to suggest that testes and ovaries show similar prepubertal $5 \alpha$-androgen synthesis in each species and that the formation of a significant quantity of $5 \alpha$-androgens may be absent in ovaries of immature humans. Prepubertal changes of gonadal $5 \alpha$-androgen biosynthesis seem to be variable in different species of animals. 

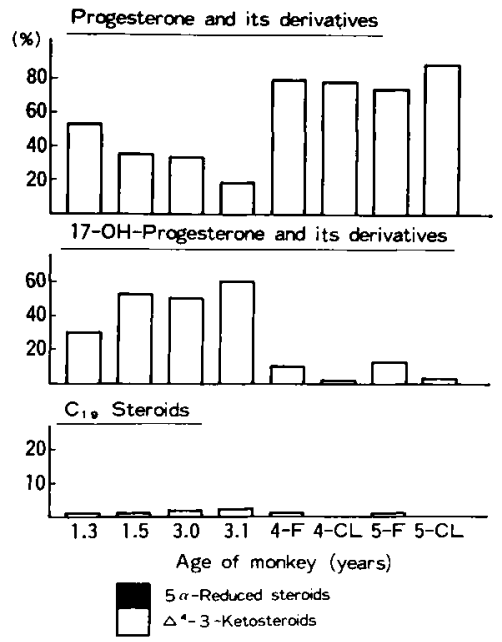

FIG. 7. - Percentoge formation of ${ }^{3} \mathrm{H}$-steroids from ${ }^{3} \mathrm{H}$-progesterone by ovarian homogenates from rhesus monkeys. Ninety $\mathrm{mg}$ tissue was incubated with ${ }^{3} \mathrm{H}$-progesterone $(1 \mathrm{nmol}: 1 \mu \mathrm{Ci}$ per fube) at $37^{\circ} \mathrm{C}$ for $2 \mathrm{hr}$ in $1 \mathrm{ml}$. F : follicles and interstitial cells. L : Corpora lutea.

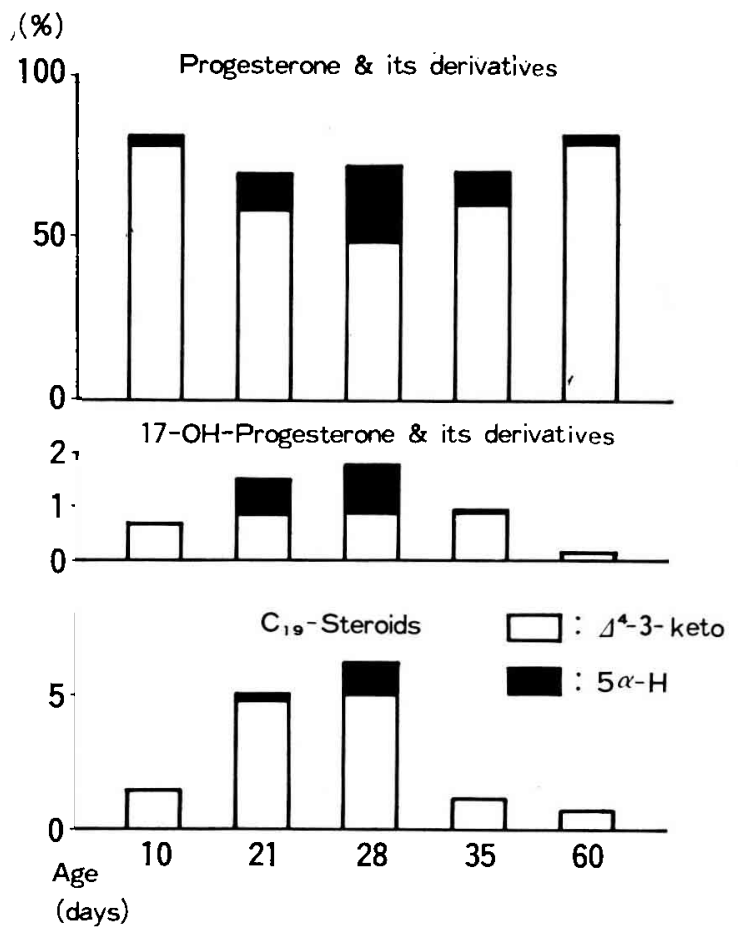

FIG. 8. - Percentage formation of ${ }^{3} \mathrm{H}$-steroids from ${ }^{3} \mathrm{H}$-progesterone by mouse ovarian homogenates. Eighty mg.tissue was incubated with ${ }^{3} \mathrm{H}$-progesterone ( $2 \mathrm{nmol}: 1 \mu \mathrm{Ci}$ per tube) at $37^{\circ} \mathrm{C}$ for $1 \mathrm{hr}$ in $1 \mathrm{ml}$. 


\section{Conclusion.}

In rats and mice, significant amounts of $5 \alpha$-androgens are synthesized in immature ovaries but not in suckling and adult ovaries. These $5 \alpha$-androgens are formed mainly by the pathway through $\mathrm{C}_{21}-5 \alpha$-steroids which is regulated by $\mathrm{LH}$. In monkey ovaries, the age dependent pattern of $5 \alpha$-androgen formation is not found.

4th Workshop on « Development and maturation of the reproductive organs and functions $»$ Luynes, France, octobre 1978.

Acknowledgments. - The authors are grateful to the National Institute of Arthritis, Metabolism and digestive Diseases, USA for their generous supply of NIH-LH-S19 and NIAMD-Rat-FSH-B-I.

Résumé. De la progestérone $\left({ }^{14} \mathrm{C}\right.$ ou $\left.{ }^{3} \mathrm{H}\right)$, de la ${ }^{3} \mathrm{H}-5 \alpha$-pregnane-3,20-dione et/ou de la ${ }^{14} \mathrm{C}$ testostérone ont été, soit incubées avec des fragments d'ovaire, soit injectées directement dans les ovaires de ratte, de souris ou de macaque rhésus de différents âges. Après ces traitements, les dérivés radioactifs ont été extraits, isolés, identifiés et mesurés soit à partir de l'incubation, soit dans le sang de la veine ovarienne.

Les ovaires des trois espèces, quel que soit l'âge, convertissent la progestérone en $17 \alpha-\mathrm{OH}$ progestérone et en androstènedione et/ou testostérone. Les ovaires de ratte ef de souris immatures synthétisent des dérivés $5 \alpha$ réduits en $C_{21}$ ou $C_{19}$ tels que le $3 \alpha, 17 \alpha$-dihydroxy-5 $\alpha$-pregnane-20-one, l'androstérone et le $5 \alpha$-androstane-3 $\alpha, 17 \beta$-diol, tandis que les ovaires de rattes ou de souris allaitantes, ainsi que ceux du Rhésus de tout âge, forment peu ou pas du tout de dérivés $5 \alpha$ réduits. Les androgènes $5 \alpha$ réduits produits par les ovaires de rongeurs immatures proviennent principalement de la voie passant par les stéroïdes en $\mathrm{C}_{21}, 5 \alpha$ réduits, qui est régulée pa $\mathrm{LH}$, mais ni par $\mathrm{FSH}$, ni par les stéroïdes sexuels.

\section{References}

COFFEY J. C., FRENCH F. S., NAYFEH S. N., 1971. Metabolism of progesterone by rat testicular homogenates. IV. Further studies of testosterone formation in immature testis in vitro. Endocrinology, 89, 865-872.

ECKSTEIN B., 1975. Studies on the mechanism of the onset of puberty in the female rat. J. Steroid Biochem., 6, 873-878.

ECKSTEIN B., RAVID R., 1974. On the mechanism of the onset of puberty : Identification and pattern of $5 \alpha$-androstane- $3 \beta, 17 \beta$-diol and its $3 \alpha$ epimer in peripheral blood of immature female rats. Endocrinology, 94, 224-229.

FICHER M., STEINBERGER E., 1971. In vitro progesterone metabolism by rat testicular tissue at different stages of development. Acta endocr., Copenh., 68, 285-292.

INANO H., HORI Y., TAMAOKI B., 1967. Effect of age on testicular enzymes related to steroid bioconversion. Ciba Fedn. Colloq. Endocr., 16, 105-119.

KARAKAWA T., KURACHI K., AONO T., MATSUMOTO K., 1976. Formation of $5 \alpha$-reduced $C_{19^{-}}$ steroids from progesterone in vitro by a pathway through $5 \alpha$-reduced $C_{21}$-steroids in ovaries of late prepubertal rats. Endocrinology, 98, 571-579.

MASON N. R., 1970. Steroid A-ring reduction by rat ovaries. Endocrinology, 87, 350-355.

MEIJS-ROELOFS H. M. A., UILENBROEK J. T. J., DE JONG F. H., WELSCHEN R., 1973. Plasma œstradiol-17 $\beta$ and its relationship to serum follicle stimulating hormone in immature female rats. J. Endocr., 59, 295-304. 
MIZUTANI S., TSUJIMURA T., AKASHI S., MATSUMOTO K., 1977. Lack of melabolism of progesterone, testosterone and pregnenolone to $5 \alpha$-products in monkey and human testes compared with rodent testes. J. clin. Endocr. Metab., 44, 1023-1031.

ODELL W. D., SWERDLOFF R. S., 1976. Etiologies of sexual maturation : a model system based on the sexually maturing rat. Recent Prog. Horm. Res., 32, 245-277.

SEKI T., MATSUMOTO K., 1967. Chromatographic separation of 17-hydroxysteroids and 17-ketosteroids. J. Chromatogr., 27, 423-430.

SPRINGER C., ECKSTEIN B., 1971. Regulation of production in vitro of $5 \alpha$-androstane-3 $\alpha, 17 \beta$-diol in the immature rat ovary. J. Endocr., 50, 431-439.

TERAKAWA N., KONDO K., AONO T., KURACHI K., MATSUMOTO K., 1978. Hormonal regulation of 4-ene-5 $\alpha$-reductase activity in prepubertal rat ovaries. J. Steroid Biochem., 9, 307-311.

TSUIMURA T., MATSUMOTO K., 1974. Progesterone metabolism in vitro by mouse testes at different stages of development. Endocrinology, 94, 288-290.

TSUJIMURA T., MIZUTANI S., MATSUMOTO K., 1975. Pathway from progesterone to $5 \alpha$-reduced $\mathrm{C}_{19}$-steroids not involving androstenedione and testosterone in immature mouse testes in vitro. Endocrinology, 96, 515-518.

YAMADA M., YASUE S., MATSUMOTO K., 1973. Formation of $C_{21}-17$-hydroxysteroids and $C_{19^{-}}$ steroids from 3 3 -hydroxy-pregn-5-en-20-one and progesterone in vitro by germ cells from immature rat testes. Endocrinology, 93, 81-87.

YAMADA M., MATSUMOTO K., 1974. Pathway from progesterone to $5 \alpha$-reduced $C_{19}$-steroids not involving androstenedione and testosterone in immature rat testes in vitro. Endocrinology, 94, 777-784.

YAMADA M., MIYAJI H., KASAI H., MATSUMOTO K., 1976. Formation of $5 \alpha$-reduced $C_{19}$-steroids from progesterone in vivo by $5 \alpha$-reduced pathway in older prepubertal rat testis. Biochim. biophys. Acta, 424, 82-89.

ZAFFARONI A., BURTON R. B., 1951. Identification of corticosteroids of beef adrenal extract by paper chromatography. J. biol. Chem., 193, 749-767. 